\title{
各種味噌の香気成分組成の比較
}

\author{
营原悦子* ・米倉裕一**
}

\section{Comparison of Aroma Components in Five Types of Miso}

\author{
Etsuko Sugawara* and Yuichi Yonekura** \\ * Faculty of Education, Iwate University, 3-18-33, Ueda, Morioka-shi, Iwate 020-0066 \\ ** Iwate Industrial Research Insutitute, 35-2, Yamori, 3, Iiokashinden, Morioka-shi, Iwate 020-0852
}

\begin{abstract}
The compositions of aroma components were compared in three types of rice miso, red salty rice miso (sekishoku-karakuchikei komemiso), thin-colored salty rice miso (tanshoku-karakuchikei komemiso), and weak-salty rice miso (komeamamiso) which were produced from soybeans and rice, barley miso (mugimiso) produced from soybeans and barley, and soy miso (mamemiso) produced from soybeans only. In addition, the influences of difference in the materials and the manufacturing process of miso on the formation of aroma in 5 types of miso were discussed. Eight samples in each type of miso were collected from products highly evaluated at the 34th National Miso Competition, and their aroma concentrates were prepared. Aroma components concentrated on a porous polymer were eluted with ether, and analyzed by gas chromatography (GC) and gas chromatography-mass spectrometry (GC-MS). The similarities among GC patterns obtained from 5 types of miso were evaluated using the concentrations of their 107 compounds detected. The results showed that the GC patterns of red salty rice miso were almost similar to those of thin-colored salty rice miso and barley miso, but not to those of both weak-salty rice miso and soy miso. 4-Hydroxy-2 (or 5)-ethyl-5 (or 2)methyl-3 (2 H)-furanone (HEMF), a character impact compound of red salty rice miso and shoyu, was identified in thin-colored salty rice miso and barley miso which are usually aged after fermentation process. However, no HEMF was detected in weak-salty rice miso and soy miso. 4-Ethylguaiacol, which was one of the characteristic aroma components in shoyu, was found in barley miso and soy miso as an important aroma component, but was not detected in miso produced from rice and soybeans.

(Received Jun. 20, 1997 ; Accepted Jan. 12, 1998)
\end{abstract}

味㽞によって香りは踷油同様，その品質を左右する重 要な母子であるにあ拘わらず，銺油に比較して解明がな かなか進まなかった，そこで，各種の香気濃縮物調製方 法を比较し，味頜の香気研究には香気の再現性がよく， 味㽞の香気にとって重要と考えられる成分が検出できる カラム濃維法が最む優れていることを埌告した ${ }^{1}$. 次に, この方法を用い, 最も一般的な赤色辛口系米味噌の香気 成分を分析し，統計的な解析方法も利用して，官能評価 と香気成分の関係について考察した ${ }^{23)}$ ）さらに蒸薏大豆 が発醉熟成を経て味哈になる過程で, 特有の香気成分が 形成されることを明らかにした．これら一連の研究か
ら, 赤色辛口系米味嘫の重要な香気成分として HEMF (4-hydroxy-2 (or 5)-ethyl-5 (or 2)-methyl-3 (2 H)furanone）を特定し，この香気成分の形成に関わる醉母 の役割についても報告しだ) 6).

一方，味眳は原料として用いる種類によって，米 味㽞, 麦味眳および豆味咱に分類される.さらに米味㽞 は味によって, 甘・甘口・辛, 色の濃淡によって白・淡 色・赤色に区別される.これらの味㽞はそれぞれ特徴的 な香気を持っているが，その香気特性を明確にする成分 は判明していない，そこで, 本研究では, 各種味咱の複 数の試料から香気濃縮物を調製し，それを分析して各香

*岩手大学教育学部（宁020-0066 岩手県盛岡市上田 3-18-33）

**岩手県工業技術センター（テ020-0852 岩手県飯岡新田 3 地割矢盛 35-2） 
気成分の濃度を算出した. 次に求めた濃度を変数とし て，統計的に処理し，各種味噌の香気特性に影響を与え る重要な香気成分の特定を試みた。ささらに，これらの結 果から，共通で用いられる大豆の加熱処理条件や棓の原 料, 仕込後の温度管理や熟成期間等の製造工程が各種味 㽞の香気形成へ及ばす影響について明らかにした。 ま た，味噌と䠓油は原料や製造工程が類似しており，前

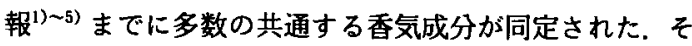
こで，整油の特徴的な香気成分として報告されている HEMF, methionol, 4-ethylguaiacol の各種味噌におけ る濃度を特定し，これらの成分と各種味咱香気の関係に ついても検討した.

\section{実 験 方 法}

\section{1. 試 料}

実験試料には第 34 回全国味咱鑑評会（1992 年, 11 月） に出品された味眳を使用した，出品された味噌は色，香 り, 味, 組成, 総合評価について全国味㽞鑑評会で従来 から行われている格付け法7で蕃查されている.そこ で，この方法で品質上位にランクされた赩辛口系米味 眳・淡色辛口系米味噌・米甘味噌・麦味㽞・豆味噌の 5 種類から，8 点ずつ選択した．従って試料数は合計 40 点 である.

2. 香気湛縮物の調製及び香気成分の分倠・同定 香気濃縮物は前報) 6) と同様にポーラスポリマーを 用いたカラム濃縮法で調製した。同種の味噌について 回同様の実験を繰り返して行った。

得られた香気濃縮物はガスクロマトグラフ（GC），お よび GCに直結したマススペクトロメーター（GC-MS） を用いて分析した，分析条件は前報2) 6) と同様である. 各香気成分の濃度は内部標準物質 (n-decylalcohol) と のピーク面積の比を基に，味眳の重量に対する ppm で 計算した。

3. カラム灅縮法による管油特有香気成分の回収率

溜油の香気成分として重要性が指摘されている HEMF, methionol, 4-ethylguaiacol ${ }^{8)}$ の 3 成分につい $\tau, 30 \mathrm{ppm}$ のモデル水溶液を調製し，以下味哈の香気 濃縮物調製方法と同様に処理し分析して，力ラム濃縮法 によるこれら成分の回収率を算出した。

\section{4. 統計的手法}

5 種類の味噌，それぞれ 8 試料の香気濃縮物を GC 分 析したところ, おわせて 107 ピークが検出された. そこ で,これら 107 成分の平均濃度を数値群とし，各種味㽞 間のガスクロマトグラムのパターン類似率を求めた9).
また， 2 種類ずつ味噌を組み合わせ，それぞれの味眳の 香気成分濃度について $\mathrm{t}$ 検定を行い，有意差のある香気 成分を検索した。

\section{実験結果および考察}

\section{1. 各種味哙香気成分の GC パターン類似率}

陚料とした赤色辛口系米味噌と㠜色辛口系米味㽞, 麦 味噌の香気の質的特徴はかなり類似していた．また，香 気の強度は赤色辛口系米味哙と麦味㽞は同程度で, 淡色 辛口系は幾分弱く，米甘味頜は最も弱かった．さらに豆 味噌は上記 3 種とはかなり異質な香気が感じられた。 こで，各種味奮香気の全体的な特徽を把握するために， 各香気成分の種類とその濃度からパターン類似率を求 め, Table 1 に示した.

最も高いパターン類似率は赤色辛口系米味噌と麦味咱 間の 0.969 であった。ついで资色辛口系米味喫と麦味咱 が 0.907 , 赤色辛口系米味咱之淡色辛口系米味咱が 0.875 となり, 赤色辛口系米味噌, 淡色辛口系米味眳, 麦味眳 の 3 種は全体的な香気組成が類似していることが判明し た.しかし，これら 3 種類の味眳と豆味眳との類似率は $0.272 \sim 0.165$, 米甘味㽞との類似率は $0.064 \sim 0.035$ と極 めて低く，香気組成がかなり異なることが示唆された。

2. 米味哈における楼造条件と香気成分の風係 米味噌は原料として蒸煮大豆と米稹を用いる。しか し，大豆に対する米透や食塩の割合，さらには仕込後の 温度管理や発酵期間によって多種類の米味噌が製造され る.ところで，味哈の熟成パターンは分解型，発酥型お

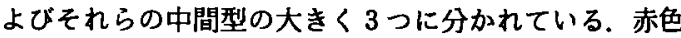
辛口系米味噌では雅かびの酵素による加水分解と酵母に よる発酶の両方によって熟成が進められており，発酵型 熟成である，米甘味眳は鹤の量を多くし，酵素の分解作 用を主にして発酵は行わない分解型熟成である，淡色辛 口系は仕込の温度が幾分高く，仕込後の酵母の活動は発 酵型に比較して，微弱なので分解型と発酵型の中間にな る. また，味眳の着色をさけるために大豆の加熱条件は 赤色系より軽い.

初めに赤色辛口系米味噌と淡色辛口系米味噌の香気成 分の濃度について $\mathrm{t}$ 検定を行うことによって，大豆の加 熱条件と発酵条件の香気成分への影翌を考察した。 Table 2 に $0.1 \%$ レベルで有意差のある成分の平均濃度 を示した. 赤色系と淡色系で有意差が認められた成分は methionol のみで，GCパターン類似率の結果もあわせ ると，両者の香気組成は極めて類似していることが判明

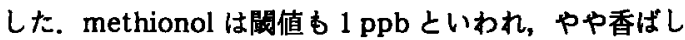


Table 1 The similarities in gas chromatographic patterns of aroma components among five different types of miso

\begin{tabular}{lcccc}
\hline \hline \multicolumn{1}{c}{$\mathrm{S}_{(\mathrm{A}, \mathrm{B})}$} & KOME 1 & KOME 2 & AMA & MUGI \\
\hline KOME 2 & 0.875 & & & \\
AMA & 0.064 & 0.035 & & \\
MUGI & 0.969 & 0.907 & 0.060 & \\
MAME & 0.165 & 0.219 & 0.015 & 0.272 \\
\hline
\end{tabular}

KOME 1, red salty rice miso (sekishoku-karakuchikei komemiso).

KOME 2, thin-colored salty rice miso (tanshoku-karakuchikei komemiso).

AMA, weak-salty rice miso (komeamamiso).

MUGI, barley miso (mugimiso).

MAME, soy miso (mamemiso).

$S_{(A, B)}$, the similarity between gas chromatogram $A$ and gas chromatogram $B$.

$$
\mathrm{S}_{(\mathrm{A}, \mathrm{B})}=\frac{\sum_{i=1}^{107} a i b i}{\sqrt{\sum_{i=1}^{107} a i^{2}} \sqrt{\sum_{i=1}^{107} b i^{2}}}
$$

$a_{1}$, concentration of peak i on GC A.

$b_{1}$, concentration of peak $i$ on GC B.

く嶩度によっては䇴油様の香気を有し，酵母のメチオ二 ン代謝により生成すると報告され，多くの釀造食品中に 検出されている ${ }^{8)}$.

methionol は赤色辛口系味眳のように低温で長期発 醇させる味噌で多く形成され，赤色辛口系と淡色辛口系 米味眳を区別する重要な香気成分であることが判明し た．また，仕込前の大豆の加熱条件は味㽞の色には大き な影響を及ばすが香気形成には影響が少ないと推察され た.

米甘味哈と赤色辛口系味㽞の香気成分の㵚度について 同様に $\mathrm{t}$ 検定を行い，有意差のある香気成分を検索して

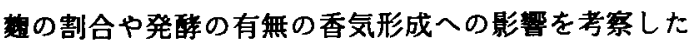
(Table 2). 赤色系と甘味咱とでは 12 種の成分で有意差 が認められた。これら成分のうち 8 種は赫色系でのみ検 出され, 他の 4 種の濃度も赤色系が甘味咱より高かっ た. また，これら有意差の認められた成分はほとんどが 醉母による発醉過程で形成される成分であった ${ }^{10)}$. 特 に，私達の一連の研究において赤色辛口系米味䁒の香気 成分として極めて重要であることが判明している HEMF() は甘味啗では検出されなかった. HEMF は味 㽞中の重要な醉母である, Zygosaccharomyces rouxii に よって生成されることは既に報告しており ${ }^{6}$ ，米甘味哙 は分解型熟成で発醉は行われないため醉母 Z. rouxii の 增殖はほとんど無く, HEMF は生成されなかったと考
えられた。

甘味㗱では他の 2 種の米味噌より検出された香気成分 数が明らかに少なく，その浱度る低かった。甘味㗱では 酵母による発醉工程がないことから，この過程で形成さ れる香気成分が検出されず, 香気が弱くなり，全体とし て異なった香気を持つ味㽞となることが判明した，以上 より，米㗑を用いて製造される味㽞では，特に発䤉過程 の有無が味㖺香気の特徴を大きく左右することが示唆さ れた.

\section{3. 原料趋と香気組成の関保}

原料とした種の類による香気組成の差異を明らかに するために，代表的な米味咱である赤色辛口系と麦味 啗, 豆味䁒の 3 種類を比較した. 赤色辛口系米味㽞と麦 味㽞, 赤色辛口系米味㕷と豆味㽞, 麦味眳と豆味眳を組 み合わせ,それぞれで浱度に有意差のある香気成分を $\mathrm{t}$ 検定を行うことによって検索した. Table 2 には $0.1 \%$ の危険率で有意差が認められた成分の平均濃度を示し た.

赤色辛口系米味噌と麦味噌で有意差の認められた成分 はフェノール化合物 2 種 (4-ethylphenol, 2-methoxy4-vinylphenol) とピラジン化合物 2種 (2,5-dimethylpyrazine, trimetylpyrazine), HMF (4-hydroxy-5methyl-3 (2 H)-furanone) の 5 種であった. 有意差が 認められた 5 種類の香気成分の濃度はすべて麦味眳で有 
Table 2 Statistically significant compounds which characterize the aroma in five different types of miso

\begin{tabular}{|c|c|c|c|c|c|c|c|c|c|c|}
\hline \multirow[b]{2}{*}{ Compounds } & \multicolumn{5}{|c|}{ Concentration" } & \multirow{2}{*}{$\begin{array}{l}\text { K } 1: \\
\text { K } 2\end{array}$} & \multirow{2}{*}{$\begin{array}{l}\text { K 1: } \\
\text { AM }\end{array}$} & \multirow{2}{*}{$\begin{array}{l}\text { K 1: } \\
\text { MG }\end{array}$} & \multirow{2}{*}{$\begin{array}{l}\text { K 1: } \\
\text { MM }\end{array}$} & \multirow{2}{*}{$\begin{array}{l}\text { MG } \\
\text { MM }\end{array}$} \\
\hline & K 1 & $\mathrm{~K} 2$ & $\mathrm{AM}$ & MG & MM & & & & & \\
\hline \multicolumn{11}{|l|}{ Aliphatic alcohols } \\
\hline 2-methyl-1-propanol & 0.784 & 0.417 & 0.015 & 0.518 & 0.033 & & $* *$ & & $* *$ & \\
\hline 3-methyl-1-butanol & 6.452 & 4.631 & 0.088 & 3.609 & 0.086 & & ** & & $* *$ & \\
\hline meso-2,3-butanediol & 0.407 & 0.268 & - & 0.392 & 0.231 & & $* *$ & & & \\
\hline L-2,3-butanediol & 0.242 & 0.146 & - & 0.472 & 0.004 & & & & & $* *$ \\
\hline hexanol & 0.022 & 0.026 & 0.002 & 0.010 & + & & & & ** & $* *$ \\
\hline 1-octen-3-ol & 0.033 & 0.049 & 0.026 & 0.076 & 0.020 & & & & & $* *$ \\
\hline \multicolumn{11}{|l|}{ Esters and acids } \\
\hline ethyl propanoate & 0.031 & 0.007 & - & 0.039 & 0.016 & & ** & & & \\
\hline methyl hexadecanoate & 0.033 & 0.008 & - & 0.051 & - & & $* *$ & & ** & \\
\hline pentanoic acid & 0.039 & 0.124 & 0.033 & 0.197 & 0.261 & & & & $* *$ & \\
\hline hexanoic acid & 0.029 & 0.016 & 0.057 & 0.039 & 0.150 & & & & ** & $* *$ \\
\hline \multicolumn{11}{|l|}{ Aromatic compounds } \\
\hline benzaldehyde & 0.018 & 0.012 & 0.010 & 0.055 & 0.045 & & & & $* *$ & \\
\hline 2-phenyl-2-butenal & 0.078 & 0.020 & - & 0.042 & 0.001 & & $* *$ & & $* *$ & \\
\hline benzenemethanol & 0.017 & 0.016 & - & 0.015 & 0.032 & & $* *$ & & & \\
\hline 4-ethylphenol & - & - & - & 0.024 & 0.137 & & & ** & & \\
\hline 4-ethylguaiacol & - & - & - & 0.195 & 0.124 & & & & $* *$ & \\
\hline 2-methoxy-4-vinylphenol & 0.099 & 0.240 & 0.058 & 0.902 & 0.171 & & & ** & & \\
\hline \multicolumn{11}{|l|}{ Furanones and pyrone } \\
\hline 3-methyl-2 $(5 \mathrm{H})$-furanone & 0.079 & 0.030 & - & 0.024 & - & & $* *$ & & ** & \\
\hline HMF & - & - & - & 0.035 & 0.030 & & & $* *$ & $* *$ & \\
\hline HDMF & 0.091 & 0.054 & - & 0.089 & 0.032 & & ** & & & \\
\hline HEMF & 3.890 & 1.654 & - & 1.864 & - & & $* *$ & & $* *$ & ** \\
\hline maltol & 2.009 & 1.058 & 0.317 & 1.676 & 1.887 & & $* *$ & & & \\
\hline \multicolumn{11}{|l|}{ Other compounds } \\
\hline methionol & 0.287 & 0.074 & 0.015 & 0.179 & - & $* *$ & ** & & $* *$ & \\
\hline 2,5-dimethylpyrazine & - & - & - & 0.014 & 0.022 & & & $* *$ & ** & \\
\hline trimethylpyrazine & - & - & - & 0.021 & 0.020 & & & $* *$ & $* *$ & \\
\hline acetylpyrrole & 0.033 & 0.021 & 0.010 & 0.028 & 1.061 & & & & $* *$ & $* *$ \\
\hline
\end{tabular}

") ppm.

$\mathrm{K} 1$, red salty rice miso (sekishoku-karakuchikei komemiso) ;

$\mathrm{K} 2$, thin-colored salty rice miso (tanshoku-karakuchikei komemiso) ;

AM, weak-salty rice miso (komeamamiso) ;

MG, barley miso (mugimiso) :

MM, soy miso (mamemiso).

-, not detected ;,$+<0.001 \mathrm{ppm} ;{ }^{* *}, \mathrm{p}<0.1 \%$.

HMF, 4-hydroxy-5-methyl-3 $(2 \mathrm{H})$-furanone ;

HDMF, 4-hydroxy-2,5-dimethyl-3 (2H)-furanone ;

HEMF, 4-hydroxy-2 (or 5)-ethyl-5 (or 2)-methy 1-3 (2 H)-furanone. 
意に高く，麦味噌は米味眳よりさらに複雑な香気組成に なっていることが示唆された。

4-ethylphenol は 4-ethylguaiacol とともに輏油の特 香成分の一つとされ，特徴的な燻煙臭を持っている，醬 油においてはこれらのフュノール化合物は小麦のリグニ ンが製新中に変化を受けて生じたフェノールカルボン酸 である ferulic acidやp-hydroxycinnamic acid が前 駆物質になり，Candida 属酵母（C. versatilis とC. etchellsii) によってアルコール発酵と同時に形成される と報告されている゙'，味㽞にす Candida 属酵母菌（C. versatilis とC. etchellsii) が存在する ${ }^{12)}$. 麦味㽞には䊍 として大麦が含まれており，䠓油と同様の経路でこれら フェノール化合物が生成されたと推定された。 また，ピ ラジン化合物と HMF は加熱香気の代表的な成分であ りこれらの成分は原料の大麦や大豆が分解されて生成 した糖やアミ/酸を前駆物質とし，発酵中の稳やかな条 件下でのアミノカルボニル反応により形成されたと推察 された．米㲘を用いた味噌ではこれらの成分は検出され ないことから，原料槒によって生成される香気成分の前 駆物質が異なると考えられた。

赤色辛口系米味噌と豆味噌では有意差の認められた成 分は 16 種と多く，香気組成がかなり異なることが判明 した，赤色辛口系米味噌では発酵過程で形成される 4 種 の成分 (2-methyl-1-propanol, 3-methyl-1-butanol, methionol, HEMF) $)^{5)}$ の濃度が有意に高かった．豆味䁚 は蒸煮大豆全体を速とし米や麦を用いないのでこれらの でんぷんから生成する糖がなく，糖を栄養源とする酵母 による発醉が弱い，従って，発酵中に酵母によって形成
される香気成分の濃度が赤色辛口系米味唨より低くなっ たと考えられた。 また，2種のピラジン化合物および HMF の濃度が豆味噌で有意に高かった，これらの成分 は原料の大豆が分解され形成された糖やアミ/酸を前駆 物質とし，発酵型就成よりさらに長期の熟成をへる豆味 噌特有の過程でアミノカルボニル反応により形成された と推察された。 また，4-ethylguaiacol は香成 分の一つとされ，闘值も $1.3 \mathrm{ppb}$ と低く，醬油中に 1 3 ppm 含まれると品質的に明確な優位性があるといわれ ている，4-ethylguaiacol は麦味咱で赤色辛口系米味噌 より有意に高かった 4-ethylphenol と同様の経路で, 大 豆表皮や胚軸に多く存在すると考えられているフェノー ルカルボン酸 ${ }^{13)}$ から形成されたと考えられた.

麦味㽞と豆味咱において有意差が認められた成分は 6 種あった．特に発酵の過程で酶母により形成され，赤色 辛口系米味䁚の特徴的な香気成分である HEMF が豆味 噌で有意に低かった。豆味噌は酵母による発酵が弱いこ とに起因すると考えられた。

以上より，原料とする麭の種類によって形成される香 気成分の種類に差が生じ，香気の特徴に大きく影響する ことが示唆された。

\section{4. 筙油特有香気成分と各種味㴰香気との関係}

醬油の香気成分に関する研究は味噌香気に関する研究 より進んでおり，Table 3 に示した HEMF, methionol, 4-ethylguaiacol が輏油の特有香気成分であることが明 らかにされている8).これらの成分はともに閾値も低く， それぞれ特徴的な香気を有している，一方，各種味㬝の 香気成分は䠓油の香気成分と共通しており，これら 3 成

Table 3 The concentrations of compounds having a characteristic aroma in five different types of miso

\begin{tabular}{|c|c|c|c|c|c|}
\hline \multirow[b]{2}{*}{ Compounds } & \multicolumn{5}{|c|}{ Concentration" } \\
\hline & KOME 1 & KOME 2 & AMA & MUGI & MAME \\
\hline HEMF & 18.178 & 7.729 & - & 8.710 & - \\
\hline methionol & 1.386 & 0.357 & 0.072 & 0.865 & - \\
\hline 4-ethylguaiacol & - & - & - & 0.855 & 0.544 \\
\hline
\end{tabular}

1), ppm.

KOME 1, red salty rice miso (sekishoku-karakuchikei komemiso) ;

KOME2, thin-colored salty rice miso (tanshoku-karakuchikei komemiso) ;

AMA, weak-salty rice miso (komeamamiso) ;

MUGI, barley miso (mugimiso) ;

MAME, soy miso (mamemiso).

-, not detected.

HEMF, 4-hydroxy-2 (or 5)-ethyl-5 (or 2)-methyl-3 (2 H)-furanone. 
分も同定された. また, Table 2 において $\mathrm{t}$ 検定の結果, HEMF と methionol は 3 種類の組み合わせで有意差か 認められ，各種味噌香気の相違を明確にする化合物であ ることが示唆された，さらに，4-ethylguaiacol 赤色 辛口系米味眳と豆味㽞において有意差のある成分であっ た. 従って，これら 3 成分の組み合わせと濃度が各種味 哈の香気特性にも大きな影響を与えると推察された。 そ こで 5 種類の味噌でこれら 3 成分の濃度を比較し，各種 味眳の香気の特徵をより明確にすることを試みた。

3 種の香気成分のカラム濃縮法による回収率を求めた ところ, HEMF では $21.4 \%, 4$-ethylguaiacol では 22.8 \%, methionol では $20.7 \%$ であった. Table 3 に回収率 をもとに換算した濃度を示した。これらの成分は香気成 分の中ではとあにかなり水溶性であり，試料は水溶液と して調製したため回収率が低くなったと推察された。

HEMF, methionol, 4-ethylguaiacol がすべて闌值を 大きく上回って検出された味咱は麦味眳のみであった。 麦味眳は镉油に最も近い香気成分を持つことが判明し， これは原料が最も醬油に近いことに起因すると推察され た.

HEMF と methionol の濃度は醉母による発醭過程を 示す重要な成分であり，発酵型熟成の赤色辛口系米味眳 ではこれら 2 成分の濃度が 5 種類中最も高かった。 ま た, HEMF と methionol の濃度はそれぞれ $18.2 \mathrm{ppm}$ $1.39 \mathrm{ppm}$ と閾值を大きく上回って存在し，これら2成 分は赤色辛口系米味哑香気の特徵を示すと判断された. 潵色辛口系米味噌は中間型熟成のために赤色辛口系米味 㽞より HEMFや methionol の濃度も7.7 ppm, 0.36 ppm と低く，赤色系より香気が弱いと判断された。 ま た，麦味咱は赤色辛口系と淡色辛口系米味咱の両熟成パ ターンに属する試料が存在しており, HEMFと methionol の濃度は中間型熟成の炏色辛口系米味眳と 同レベルになったと考えられた。また，甘味噌は 0.07 ppm の methionol が検出されたのみであり，特徴的な 香気が弱いと判断された。豆味噌からはHEMFと methionol は検出されず, 麦味咍, 米味眳とはかなり異 なった香気特性を持つことが示唆された。

4-ethylguaiacol は3 種の米味眳からは検出されず, 麦味咱で $0.86 \mathrm{ppm}$, 豆味㽞で $0.54 \mathrm{ppm}$ 検出された. 4ethylguaiacol は米䴯を用いた味眳と，米䞟を用いない 麦味咱，豆味哈を区別する重要な香気成分であると考え られた。

Table 2 において有意差が示された香気成分の中であ 特に，特徴的な香気を持つ HEMF, methionol, 4-ethyl- guaiacol の組み合わせと濃度が各種味噌の香気の特徽 に影響を与えていると考えられた。

\section{要 約}

味㽞は原料種類や，味，色の濃淡によって区別さ れ，それぞれ特徴的な香気を持っている，そこで，大豆 と米加製造される 3 種類の米味啗, 赤色辛口系米味 噌・淡色辛口系米味噌・米甘味噌之，大豆と大麦加製 造される麦味噌, 大豆のみから製造される豆味㽞の香気 成分の組成を明らかにし，5種類の味噌の香気形成への 原料や製造工程の影響について検討した。

香気濃縮物は 5 種類の味噌, それぞれ 8 点ずっ合計 40 点から調製し，ガスクロマトグラフとガスクロマトグラ フーマススペクトロメトリーを用いて分析し各香気成分 の濃度を算出した．求めた濃度を変数として，統計的に 処理した.

（1） 5 種類の味㽞間のガスクロマトグラムのパターン 類似率は赤色辛口系米味㗱, 淡色辛口系米味㗱, 麦味眳 の3 種間では極めて高かった。しかし、これら 3 種類の 味咱之豆味咱, 米甘味眳の類似率は低かった。

（2）赤色辛口系米味㽞と淡色辛口系米味哈の比較では 有意差が認められた香気成分は 1 種類のみで両者は極め て類似した香気組成をもつことが判明した，米甘味眳と 赤色辛口系との比較では 12 種類の香気成分で有意差が あった．米数を用いて製造される味眳では，特に発醉過 程の有無が香気の特徴を大きく左右することが示唆され た.

（3）赤色辛口系米味哈では麦味哈，豆味㽞よりフェ ノール化合物とピラジン化合物の濃度が有意に低かっ た. 豆味哈では赤色辛口系米味哈や麦味啗より $\mathrm{HEMF}$ などの醉母によって発酵過程で形成される香気成分の濃 度が有意に低かった．原料とする数の種類によって形成 される香気成分の種類に差が生じることが示唆された。

(4) 4-ethylguaiacol は整の違いによる，米味㽞と豆 味噌・麦味噌の香気を判別するのに重要な成分であり, HEMF と methionol は酵母による発醉の過程を示す重 要な成分であることが示唆された，それぞれ特徴的な香 気を有するこれら 3 成分の組み合わせと濃度が各種味眳 の香気特性に大きな影帮を与えると判断された。

終わりに臨み，本研究にご協力下さいました長田由喜 子氏に心から感謝いたします，また，試料をご提供下さ いますとともに貫重なご助言を下さいました中央味哈研 究所海老根英雄氏，藤波博子氏，本研究を行うにあたり 
ご指導ご助言を賜りましたお茶の水女子大学小林彰夫教 授，岩手大学櫻井米吉教授に謝意を表します。

\section{文献}

1）营原㙂子 - 伊東哲雄 - 小田切敏 - 久保田紀久枝 小林彰夫 : 農化, 64, 171 (1990).

2）菅原悦子 - 雑賀 優 - 小林彰夫 : 日食工誌, 39, 1098 (1992).

3) Sugawara, E., Saiga, S. and Kobayashi, A. : Nippon Shokuhin Kgyo Gakkaishi, 41, 844 (1994).

4）菅原悦子: 日食工誌，38，491（1991）.

5）营原悦子：日食工誌，38，1093 (1991).

6) Sugawara, E., Hashimoto, S., Sakurai, Y. and
KoBay ashi, A. : Biosci. Biotec. Biochem., 58, 1134 (1994).

7）西島佳子・藤波博子・島崎寿賀子・綾部浩太郎・ 海老根英雄 : 味噌の科学々技術，40，385 (1992).

8）佐々木正興・森 修三:酾協, 86, 913 (1991).

9）相島鐵郎：ケモメトリックス第 1 版（丸善, 東 京), p. 84 (1992).

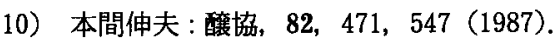

11）横塚 保・佐々木正興 - 布村伸武 - 浅尾保夫 : 醸 協，75，516，717（1980）.

12）今井誠一：新潟食品研究所研究報告特別号, p. 40 (1984).

13) Arai, S : Agric. Biol. Chem., 30, 364 (1966).

(平成 9 年 6 月 20 日受付, 平成 10 年 1 月 12 日受理) 